\title{
PENGARUH PRODUK DAN PROMOSI PENJUALAN TERHADAP VOLUME PENJUALAN PADA PT. DELAMIBRANDS KHARISMA BUSANA CABANG PALEMBANG
}

\author{
Syahyuni $^{1)}$, Hisbullah Basri ${ }^{2}$, Dimas Pratama Putra ${ }^{3)}$ \\ 1,2) Manajemen, Universitas Tridinanti Sumatera Selatan, Indonesia \\ ${ }^{3)}$ Akuntansi, Universitas Tridinanti Sumatera Selatan, Indonesia \\ Email ; ${ }^{1)}$ syahyuni2618@gmail.com, ${ }^{23}$ hisbullahbasri@gmail.com, ${ }^{3)}$ dimaspratamaputra@univ-tridinanti.ac.id
}

\begin{tabular}{|c|c|}
\hline INFORMASI ARTIKEL & $A B S T R A K$ \\
\hline $\begin{array}{l}\text { Submitted: } \\
\text { 15/11/2021 } \\
\text { Revised: } \\
\text { 12/12/2021 } \\
\text { Accepted: } \\
\text { 25/12/2021 } \\
\text { Online-Published: } \\
\text { 31/12/2021 }\end{array}$ & 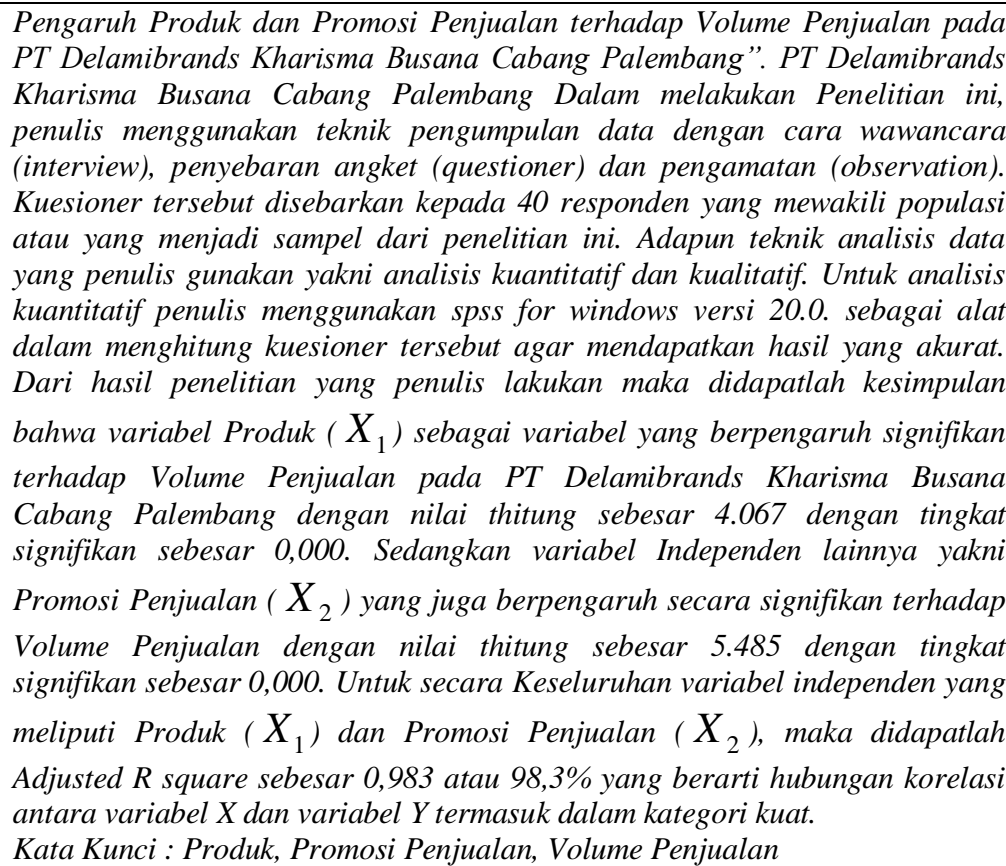 \\
\hline
\end{tabular}

\begin{abstract}
The Effect of Product and Sales Promotion on Sales Volume at PT Delamibrands Kharisma Busana Palembang Branch". PT Delamibrands Kharisma Busana Palembang Branch In conducting this research, the authors used data collection techniques by means of interviews (interviews), questionnaires (questionnaires) and observations (observation). The questionnaire was distributed to 40 respondents who represent the population or who are the samples of this study. The data analysis techniques that the author uses are quantitative and qualitative analysis. For quantitative analysis, the author uses SPSS for Windows version 20.0. as a tool in calculating the questionnaire in order to get accurate results. From the results of the research that the author did, it was concluded that the Product variable ( ) as a variable that had a significant effect on Sales Volume at PT Delamibrands Kharisma Busana Palembang Branch with a tcount of 4,067 with a significant level of 0.000. While the other independent variable is Sales Promotion ( ) which also has a significant effect on Sales Volume with a tcount of 5.485 with a significant level of 0.000. For the overall independent variables which include Product ( ) and Sales Promotion ( ), then the Adjusted $R$ square of 0.983 or $98.3 \%$ is obtained, which means that the correlation between $X$ and $Y$ is included in the strong category.

Keywords: Product, Sales Promotion, Sales Volume
\end{abstract}

http://www.univ-tridinanti.ac.id/ejournal/index.php/ekonomi/index 


\section{A. PENDAHULUAN}

Seperti yang kita ketahui beberapa tahun belakangan ini konsumen memiliki kecendrungan untuk lebih selektif terhadap produk atau jasa yang akan dibeli atau dinikmati. Persaingan dalam dunia bisnis yang semakin ketat, sehingga menuntut manajemen perusahaan PT Delamibrands Kharisma Busana Cabang Palembang untuk lebih cermat dalam menentukan strategi bersaingnya, agar dapat memenangkan dalam persaingan yang dihadapinya. Manajemen perusahaan dituntut untuk dapat mendesain dan mengimplementasi strategi pemasaran yang mampu menciptakan, mempertahankan dan meningkatkan kepuasan pelanggan, yang pada akhirnya dapat tercipta loyalitas yang tinggi dari konsumen terhadap produk yang ditawarkan.

Syarat yang harus dipenuhi oleh suatu perusahaan agar dapat mencapai sukses dalam persaingan adalah berusaha mencapai tujuan untuk menciptakan dan mempertahankan pelanggan. Agar tujuan tersebut tercapai, maka setiap perusahaan harus berupaya menghasilkan dan menyampaikan barang dan jasa yang diinginkan konsumen dengan harga yang pantas. Dengan demikian, setiap perusahaan harus mampu memahami kelangsungan hidup perusahaan tersebut sebagai organisasi yang berusaha memenuhi kebutuhan dan keinginan para konsumen sangat tergantung pada perilaku konsumennya (Tjiptono,2008: 129).

Dalam memasarkan produknya PT Delamibrands Kharisma Busana harus mempertimbangkan perilaku konsumen. Perilaku konsumen sendiri dapat diartikan sebagai suatu kegiatan-kegiatan individu yang secara langsung terlibat dalam mendapatkan serta menggunakan barangbarang dan jasa, termasuk didalamnya proses pengambilan keputusan pada persiapan dan penerapan kegiatan (Basu Swastha, 2005: 30).(Kotler \& Armstrong (2008: 29) mengatakan bahwa kualitas produk merupakan senjata strategis yang potensial untuk mengalahkan pesaing. Jadi hanya perusahaan dengan menghasilkan kualitas paling baik akan tumbuh dengan pesat, dan dalam jangka panjang perusahaan tersebut akan lebih berhasil dari perusahaan yang lain.
Kualitas produk erat hubungannya dengan baik buruknya suatu produk, karena kualitas produk merupakan elemen penilaian konsumen terhadap produk yang diinginkan. Kualitas produk menjadi penting, karena dengan terciptanya produk yang unggul dan baik maka akan mendorong konsumen dalam melakukan pembelian produk tersebut.

Faktor yang perlu di pertimbangkan dalam pemasaran selain kualitas produk adalah harga. Sesuai dengan saluran distribusi merk Wrangler, Wood, The Executive, Et Cetera, Colorbox, Lee dan Tirajeans,penetapan harga produk pakaian PT. Delamibrands Kharisma Busana akan mendapatkan perhatian yang besar dari konsumen.Jika harga yang ditetapkan oleh perusahaan tepat dan sesuai dengandaya beli konsumen maka pemilihan suatu produk akan dijatuhkan pada produk tersebut. Perusahaan menetapkan harga karena berbagai pertimbangan, dimana dalam penetapan harga tersebut disesuaikan juga dengan kualitas produk yang ada, karena produk PT. Delamibrands kharisma busana termasuk jenis produk shopping goods yaitu produk yang dalam proses pemilihan dan pembeliannya dibandingkan oleh konsumen diantara berbagai alternatif yang tersedia. PT. Delamibrands Kharisma Busana mempunyai pasar sasaran kalangan menengah keatas.

Dalam mengkomunikasikan produk dan harga kepada konsumen melalui kegiatan promosi juga merupakan suatu hal penting. Promosi merupakan kegiatan-kegiatan yang dilakukan perusahaan untuk menonjolkan keistimewaan-keistimewaan atau keunggulan produk dan membujuk konsumen untuk membeli. Setiap usaha selalu melakukan kegiatan pemasar yang didalamnya termasuk strategi pemasar yang terdiri dari srategi produk, promosi, harga, dan distribusi. Promosi bertujuan untuk menyebarluaskan informasi suatu produk kepada calon konsumen yang potensial, mendapatkan konsumen baru dan menjaga loyalitas konsumen tersebut, menaikkan penjualan, mengunggulkan produk dibanding dengan kompetitor dan membentuk citra produk di mata konsumen sesuai dengan yang diinginkan.

Di zaman yang semakin maju ini produk pakaian banyak bermunculan dengan 
bermacam gaya, fashion dan harga yang berbeda pula sehingga membuat para konsumen ataupun pelanggan PT. Delamibrands Kharisma Busana untuk mencoba produk-produk baru tersebut pada brand atau merek lain. Maka konsumen dituntut untuk menilai suatu produk yang menurut konsumen adalah yang terbaik dibanding merek lainnya. Keadaan ini mempunyai dampak pada volume penjualan pada suatu produk.

\section{Pemasaran}

Pemasaran merupakan aktivitas penting yang dilakukan suatu perusahaan yang bergerak dalam bidang apapun, baik memproduksi barang maupun jasa. Perusahaan di tuntut agar dapat memasarkan produknya semaksimal mungkin sampai tercapainya target yang telah ditentukan perusahaan sehingga dapat memperoleh laba sesuai dengan tujuan perusahaan di tambah lagi bagaimana caranya agar perusahaan memberikan yang terbaik bagi konsumen, melalui pemenuhan kebutuhan konsumen dengan baik, sehingga tercapainya kepuasan. Adanya persaingan pasar juga memacu setiap perusahaan dapat memahami kebutuhan dan keinginan dari konsumen.

Agar dapat memahami pengertian yang lebih jelas mengenai apa yang di maksud dengan pemasaran, diantara nya sebagai berikut :

Menurut Hasan (2013:4) Pemasaran adalah proses mengidentifikasi, menciptakan dan mengkomunikasikan nilai, serta memelihara hubungan yang memuaskan pelanggan untuk memaksimalkan keuntungan perusahaan.

\section{Pengertian Manajemen Pemasaran}

Manajemen pemasaran berasal dari dua kata yaitu manajemen dan pemasaran. Menurut Kotler (2012:146) manajemen pemasaran adalah penganalisaan, pelaksanaan, pengawasan, program-program yang ditunjukkan untuk mengadakan pertukaran dengan pasar yang dituju dengan maksud untuk mencapai tujuan organisasi.

Hal ini sangat tergantung pada penawaran organisasi dalam memenuhi kebutuhan dan keinginan pasar tersebut serta menentukan harga, mengadakan komunikasi, dan distribusi yang efektif untuk memberitahu, mendorong serta melayani pasar.

Menurut Alma (2012:130) definisi manajemen pemasaran diuraikan sebagai berikut :"Manajemen pemasaran adalah kegiatan menganalisa, merencanakan, mengimplementasikan, dan mengawasi segala kegiatan (program), guna memperoleh tingkat pertukaran yang menguntungkan dengan pembeli dalam rangka tujuan organisasi”.

\section{Pengertian Bauran Pemasaran}

Menurut Lupiyoadi dan Hamdani (2009:70) Dalam manajemen pemasaran jasa mengatakan bauran pemasaran adalah sebagai berikut :

"Bauran Pemasaran (Marketing Mix) adalah alat bagi pemasar yang terdiri atas berbagai unsur suatu program pemasaran yang perlu di pertimbangkan agar implementasi strategi pemasaran dan positioning yang ditetapkan dapat berjalan sukses"

Kotler dan Amstrong (2012:52) juga menjelaskan bahwa ada 7 konsep yang tercakup dalam kegiatan bauran pemasaran (marketing mix) yang terkenal dengan sebutan 7P.

\section{Produk (product)}

Salah satu dari bauran pemasaran adalah produk, keunggulan suatu produk merupakan daya tarik tersendiri yang harus dimiliki bagi suatu perusahaan agar produk tersebut dapat diandalkan di pasar sasaran. Untuk memenangkan persaingan dalam usahanya, perusahaan harus mengembangkan persaingan dalam usahanya, perusahaan harus mengembangkan dan menyempurnakan kembali serta menambah produk guna memuaskan kebutuhan dan keinginan konsumen.

\section{Harga (price).}

Harga merupakan satu-satunya unsur bauran pemasaran yang meningkatkan pendapatan sedangkan yang lain menimbulkan biaya. Harga merupakan unsur yang paling fleksibel dapat diubah dengan cepat.

Menurut Basu Swasta dan Sukotjo (2000:2011) harga adalah sejumlah uang (ditambah beberapa dibutuhkan untuk 
mendapatkan sejumlah kombinasi barang jika memungkinkan) yang dari barang beserta pelayanannya.

\section{Promosi (promotion).}

Pengertian promosi menurut Buchari Alma, dalam bukunya Ratih hurryati (2005:58-61) adalah suatu bentuk komunikasi pemasaran yang merupakan aktifitas pemasaran yang berusaha menyebarkan informasi, mempengaruhi/membujuk dan mengingatkan pasar sasaran atas perusahaan dan produknya agar bersedia menerima, membeli, dan loyal pada produk yang ditawarkan perusahaan yang bersangkutan.

\section{Saluran Distribusi (place)}

Saluran distribusi merupakan kegiatan penyampaian produk dari produsen ke konsumen yang akan menjangkau pasar yang tepat dan waktu yang tepat. Merupakan salah satu kebijakan distribusi mencakup penentuan saluran pemasaran dan distribusi fisik dalam memberikan kemudahan akses terhadap produk bagi para konsumen dalam memperoleh suatu produk yang tersedia.

\section{Partisipan (people).}

Yang dimaksud partisipan disini adalah karyawan penyedia jasa layanan maupun penjualan, atau orang-orang yang terlibat secara langsung maupun tidak langsung dalam proses layanan itu sendiri, misalnya dalam jasa kecantikan diantaranya adalah Receptionist, Dokter, dan Beauty Therapist.

\section{Proses (process).}

Proses adalah kegiatan yang menunjukkan bagaimana pelayanan diberikan kepada konsumen selama melakukan pembelian barang. Pengelola usaha melalui front liner sering menawarkan berbagai macam bentuk pelayanan untuk tujuan menarik konsumen.

7. Lingkungan Fisik (Physical evidence).

Lingkungan Fisik adalah keadaan atau kondisi yang di dalamnya juga termasuk suasana. Karakteristik lingkungan fisik merupakan segi paling nampak kaitannya dengan situasi. Yang dimaksud dengan situasi ini adalah situasi dan kondisi geografi dan lingkungan institusi, dekorasi, ruangan, suara, aroma, cahaya, cuaca, peletakan dan layout yang nampak atau lingkungan yang penting sebagai objek stimulus..

\section{Bauran Promosi}

Basu Swastha D dan Irawan (2001 : 349), bahwa Promotion mix adalah kombinasi strategi yang paling baik dari variabel-variabel periklanan, personal selling dan alat promosi yang lain, yang semuanya direncanakanuntuk mencapai tujuan program penjualan.

Dalam bauran promosi terdapat lima komponen, secara rinci dijabarkan sebagai berikut:

A. Periklanan (Advertising),

B. Penjualan Personal (Personal Selling),

C. Promosi Penjualan (Sales Promotion),

D. Publisitas dan Hubungan Masyarakat (Publicity and Public Relation),

E. Informasi dari mulut ke mulut (word of mouth),

\section{Pengertian Penjualan}

Pengertian penjualan

menurut

Henry Simamora

$(2000 ; 24)$

menyatakanbahwa:"Penjualan adalah pendapatan lazim dalam perusahaan dan merupakan volume kotor yang dibebankan kepada pelanggan atas barang dan jasa".PengertianpenjualanmenurutChairulM $\operatorname{arom}(2002 ; 28)$ menyatakanbahwa

:"Penjualan artinya penjualan barang dagangan sebagai usaha pokok perusahaan yang biasanya dilakukan secara teratur".

\section{Klasifikasi Transaksi Penjualan}

Ada beberapa macam transaksi penjualan menurut La Midjan $(2001 ; 170)$ dapat diklasifikasikan sebagai berikut:
a. Penjualan Tunai
b. Penjualan Kredit
c. Penjualan Tender
d. Penjualan Ekspor
e. Penjualan Konsinyasi
f. Penjualan Grosir

\section{Dokumen-Dokumen Penjualan}

Dokumen-dokumen penjualan menurut La Midjan $(2001 ; 183)$ antara lain sebagai berikut:
a. Order Penjualan Barang (Sales Order)
b. Nota Penjualan Barang
c. Perintah Penyerahan Barang (Delivery Order)
d. Faktur Penjualan (Invoice)
e. Surat Pengiriman Barang (Shipping Slip)
f. Jurnal Penjualan (Sales Journal) 


\section{Bagian-Bagian Penjualan}

Krismiaji (2002;275) dalam bukunya menyatakan bahwa bagian-bagian penjualan dibagi menjadi beberapa bagian, yaitu:

a. Bagian Penjualan

Adalah bagian penjualan menerima surat pesanan dari pihak pembeli dan membuat surat order penjualan atas dasar surat pesanan tersebut.

b. Bagian Kredit

Adalah atas dasar surat pesanan dari pembeli yang diterima dibagian penjualan, bagian ini memeriksa data kredit pelanggan yang selanjutnya memberikan persetujuan terhadap surat pesanan tersebut dan memeriksannya ke bagian gudang.

c. Bagian Gudang

Adalah bagian gudang yang bertugas untuk menyimpan persediaan baran dagangan serta mempersiapkan barang dagangan yang akan dikirim kepada pembeli.

d. Bagian Pengiriman

Adalah bagian ini mengeluarkan surat order penjualan dan kemudian membuat nota pengiriman atas barang yang dipesan.

e. Bagian Penagihan

Adalah bagian ini bertugas untuk membuat faktur penjualan dan kemudian didistribusikan kepada:

1) Rangkap pertama (asli) diberikan kepada pelanggan.

2) Rangkap kedua diberikan kepada bagian piutang.

3) Rangkap ketiga diarsipkan brdasarkan nomor urut bersamaam dengansurat order penjualan.

\section{Tujuan Penjualan}

Dalam suatu perusahaan kegiatan penjualan adalah kegiatan yang penting, karena dengan adanya kegiatan penjualan tersebut maka akan terbentuk laba yang dapat menjamin kelangsungan hidup perusahaan.

Tujuan umum penjualan yang dimiliki oleh perusahaan menurut Basu Swastha (2005: 404) yaitu:

a. Mencapai volume penjualan tertentu.

b. Mendapat laba tertentu.

c. Menunjang pertumbuhan perusahaan.
Faktor-faktor Yang Mempengaruhi Penjualan

Aktivitas penjualan banyak dipengaruhi oleh faktor tertentu yang dapat meningkatkan aktivitas perusahaan, oleh karena itu manajer penjualan perlu memperhatikan faktor-faktor yang mempengaruhi penjualan. Faktor-faktor yang mempengaruhi penjualan menurut Basu Swastha $(2005 ; 406)$ antara lain sebagai berikut:

a. Kondisi dan Kemampuan Penjual

Kondisi dan kemampuan terdiri dari pemahaman atas beberapa masalah penting yang berkaitan dengan produk yang dijual, volume dan sifat dari tenaga penjual adalah:

1) Jenis dan karakteristik barang atau jasa yang ditawarkan

2) Harga produk atau jasa

3) Syarat penjualan, seperti: pembayaran, pengiriman

b. Kondisi Pasar

Pasar sebagai kelompok penbelian atau pihak yang menjadi sasaran dalam penjualan dan dapat pula mempengaruhi kegiatan penjualannya.

c. Modal

Modal atau dana sangat diperlukan dalam rangka untuk mengangkut barang dagangan ditempatkan atau untuk membesar usahanya.

d. Kondisi Organisasi Perusahaan

Pada perusahan yang besar, biasanya masalah penjual ini ditangani oleh bagian tersendiri, yaitu bagian penjualan yang dipegang oleh orang-orang yang ahli dibidang penjualan.

e. Faktor-faktor lain

Faktor-faktor lain seperti periklanan, peragaan, kampanye, dan pemberian hadiah sering mempengaruhi penjualan karena diharapkan dengan adanya faktorfaktor tersebut pembeli akan kembali membeli lagi barang yang sama.

\section{Proses Penjualan}

Basu Swastha (2005;410) menyebutkan beberapa tahapan penjualan, yaitu:

1) Persiapan Sebelum Penjualan

Pada tahap ini kegiatan yang dilakukan adalah mempersiapkan tenaga penjual dengan memberikan pengertian tentang 
barang yang dijualnya, pasar yang di tuju, dan teknik-teknik penjualan yang harus dilakukan

2) Penentuan Lokasi Pembeli Potensial

Dari lokasi ini dapatlah dibuat sebuah daftar tentang orang-orang atau perusahaan yang secara logis merupakan pembeli potensial dari produk yang ditawarkan.

3) Pendekatan Pendahuluan

Berbagai macam informasi perlu dikumpulkan untuk mendukung penawaran produknya kepada pembeli, misalnya tentang kebiasaan pembeli, kesukaan, dan sebagainya. Semua kegiatan ini dilakukan sebagai pendekatan pendahuluan terhadap pasarnya.

4) Melakukan Penjualan

Penjualan dilakukan bermula dari suatu usaha untuk memikat perhatian calon pembeli, kemudian diusahakan untuk menarik daya tarik mereka. Dan akhirnya penjual melakukan penjualan produknya kepada pembeli.

5) Pelayanan Sesudah Penjualan

Dalam tahap akhir ini penjual harus berusaha mengatasi berbagai macam keluhan atau tanggapan yang kurang baik dari pembeli. Pelayanan penjualan ini dimaksudkan untuk memberikan jaminan kepada pembeli bahwa keputusan yang diambilnya tepat dan barang yang dibelinya betul-betul bermanfaat.

\section{B. METODE PENELITIAN}

Metode yang digunakan penulis dalam penelitian ini adalah metode deskripsif kualitatif yang dapat diartikan ialah membangdingkan fakta yang diperoleh dan pengetahuan teoritis yang relevan dan masalah yang sedang diteliti. Dan analisis kuantitatif adalah melakukan penelitian dengan menggunakan data yang diperoleh dari perusahaan. Dalam penulisan laporan akhir ini penulis menggunakan kedua teknik tersebut yaitu data analisis kualitatif dan kuantitatif.

Waktu pelaksanaan penelitian ini dilaksanakan selama 5 bulan yaitu dari bulan mei sampai bulan september 2019.Tempat penelitian yang dilakukan di PT. Delamibrands Kharisma Busana Cabang Palembang yang beralamat Palembang Indah Mall It 1, Jalan Letkol Iskandar No.18, 24 ilir, Kecamatan Bukit Kecil, Kota Palembang. Sumatera Selatan 30134.

Pengembangan instrumen dilakukan melalui tahapan mengkaji teori yang berkaitan dengan variabel yang diteliti. Variabel dependen dalam penelitian ini adalah Volume Penjualan (Y) dan sebagai variabel independen adalah Produk $\left(X_{1}\right)$,dan Promosi Penjualan $\left(X_{2}\right)$.

Pengumpulan data yang digunakan pada penelitian ini menggunakan wawancara (interview) dan kuesioner(angket). Populasi dalam penelitian ini adalah beberapa konsumen PT. Delamibrands Kharisma Busana Cabang Palembang yang berjumlah 40 orang pelanggan yang termasuk member Delami Card. Semetara itu yang menjadi sampel dalam penelitian adalah beberapa konsumen PT. Delamibrands Kharisma Busana Cabang Palembang yang berjumlah 40 orang baik untuk uji coba instrument maupun data penelitian. Uji coba instrumen menggunakan bantuan program Microsoft Excel 2007 for Windows dan pengujian hipotesis menggunakan bantuan program SPSS 20.00 for Windows. Teknik analisis data yang digunakan antara lain: (1) Metode Regresi Linier Berganda, (2) Metode Koefisien Korelasi $\left(R^{2}\right)$, (3) Metode Koefisien Determinasi dan (4) Uji Hipotesis.

\section{HASIL DAN PEMBAHASAN}

Pengujian Hipotesis dilakukan untuk mengetahui ada tidaknya korelasi (hubungan) antara variabel bebas dengan variabe terikat. Pengujian Hipotesis ini menggunakan taraf signifikansi 5\%.

\section{Analisis Regresi Linear Berganda}

Tabel 1. Persamaan Regresi Berganda

Coefficiests $^{2}$

\begin{tabular}{|c|c|c|c|c|c|c|}
\hline \multirow[b]{2}{*}{ Hodel } & & \multicolumn{2}{|c|}{ Unstandardiged Coefficients } & \multirow{2}{*}{$\begin{array}{c}\begin{array}{c}\text { Standardeet } \\
\text { Coefficients }\end{array} \\
\text { Bata }\end{array}$} & \multirow[b]{2}{*}{1} & \multirow[b]{2}{*}{ Sig } \\
\hline & & B & Sid. Envor & & & \\
\hline \multirow[t]{3}{*}{1} & (Constant) & 721 & .753 & & 972 & 339 \\
\hline & PRODUK_X1 & 392 & .096 & .424 & 4.067 & 000 \\
\hline & $\begin{array}{l}\text { PROMOS_PENULULAN_ } \\
X_{2}\end{array}$ & .360 & .066 & .572 & 5485 & 000 \\
\hline
\end{tabular}

a. Dependent Variahla: VouJV_PENULLAN_Y

$\mathrm{Y}=\alpha+\mathrm{b}_{1} \mathrm{x}_{1}+\mathrm{b}_{2} \mathrm{x}_{2}+\mathrm{e}$

$\mathrm{Y}=0.731+0.392+0.360+\mathrm{e}$ 
Dari persamaan diatas dapat dijelaskan sebagai berikut :

1. Konstanta $(\alpha)$ sebesar 0.731 menyatakan bahwa jika variabel independen dikatakan konstan atau $=0$ Maka Volume Penjualan hanya sebesar 0.731 .

2. Koefisien regresi Produk $\left(b_{1}\right)$ sebesar 0,392 hasil tersebut dapat diartikan bahwa setiap peningkatan Produk sebesar $1 \%$ maka akan mengakibatkan peningkatan Volume Penjualan 0,392. Semakin besar Produk yang diberikan oleh sebuah perusahaan maka semakin baik Volume Penjualan.

Koefisien regresi Promosi Penjualan $\left(b_{2}\right)$ sebesar 0,360 hasil tersebut dapat diartikan bahwa setiap peningkatan Promosi Penjualan $1 \%$ maka akan meningkatkan Volume Penjualan sebesar 0,360. Semakin besar peningkatan Promosi Penjualan maka semakin baik Volume Penjualan.

\section{Uji Koefisien Korelasi}

\section{Tabel 2. Uji Koefisien Korelasi}

Model Summary
\begin{tabular}{|c|c|r|r|r|}
\hline Model & R & R Square & $\begin{array}{c}\text { Adjusted R } \\
\text { Square }\end{array}$ & $\begin{array}{c}\text { Std. Error of } \\
\text { the Estimate }\end{array}$ \\
\hline 1 & $.991^{\mathrm{a}}$ & .983 & .982 & .799 \\
\hline
\end{tabular}
a. Predictors: (Constant), PROMOSI_PENJUALAN_X2,
PRODUK_X1

Berdasarkan tabel diatas, hasil SPSS mengenai korelasi antara variabel Produk ( $\left.X_{1}\right)$ dan Promosi Penjualan $\left(X_{2}\right)$ dengan variabel Volume Penjualan $(\mathrm{Y})$ didapat nilai $\mathrm{R}$ sebesar 0,991. Perolehan nilai koefisien korelasi (R) artinya bila variabel Produk ( $X_{1}$ ) dan Promosi Penjualan $\left(X_{2}\right)$ mempunyai hubungan tergolong kuat (erat) dengan Volume Penjualan (Y).

\section{Koefisien Determinasi $\left(R^{2}\right)$}

Perolehan nilai $\mathrm{R}$ Square merupakan koefisien determinasi. Nilai koefisien determinasi pada tabel 4.4 sebesar 0,983 atau $98,3 \%$. Koefisien determinasi digunakan untuk mengetahui presentase pengaruh variabel independen terhadap perubahan variabel dependen. Dari hasil pengolahan data tersebut diperoleh nilai koefisien determinasi sebesar 0,983. Artinya pengaruh besarnya variabel independen (Y) adalah 98.3\% sedangkan sisanya sebesar $1,7 \%$ dipengaruhi oleh variabel lain yang tidak diteliti.

\section{Uji Hipotesis}

Tabel 3. Hasil Uji Simultan (Uji F)

\begin{tabular}{|c|c|c|c|c|c|c|}
\hline \multicolumn{7}{|c|}{ ANOVA ${ }^{3}$} \\
\hline Nodel & & $\begin{array}{l}\text { Sum of } \\
\text { Squares }\end{array}$ & df & Mean Square & $\mathrm{F}$ & Sig. \\
\hline \multirow[t]{3}{*}{1} & Regression & 1369.370 & 2 & 684.685 & 1073.235 & $.000^{\mathrm{b}}$ \\
\hline & Residual & 23.605 & 37 & .638 & & \\
\hline & Total & 1392975 & 39 & & & \\
\hline
\end{tabular}

a. Dependent Variable: VOLUME_PENWUALAN_Y

b. Predictors: (Constant, PROMOSI_PENUUALAN_X2, PRODUK_X1

Berdasarkan Tabel 4.5, dapat dilihat bahwa nilai $F_{\text {hitung }}$ sebesar 1073,235 sementara untuk $F_{\text {tabel }}$ sebesar 2.451 , hal ini berarti semua variabel bebas secara bersama-sama, produk dan promosi penjualan berpengaruh terhadap volume penjualan PT. Delamibrands Kharisma Busana cabang Palembang secara signifikan.

Tabel 4. Hasil Uji Parsial (Uji t)

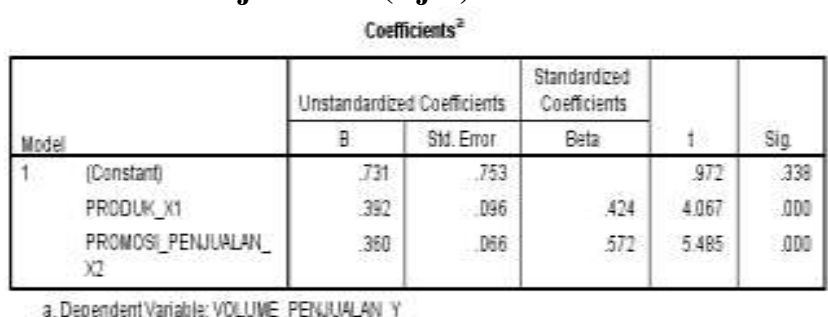

Hasil analisis uji t adalah sebagai berikut :

1. Nilai $t_{\text {hitung }}$ pada variabel Produk $\left(X_{1}\right)$ adalah sebesar 4.072 dengan tingkat signifikan sebesar 0,000 karena signifikannya $0,000<0,05$ maka $\mathrm{H} 0$ ditolak, Artinya Produk berpengaruh signifikan terhadap Volume Penjualan.

2. Nilai $t_{\text {hitung }}$ pada variabel Promosi Penjualan $\left(X_{2}\right)$ adalah sebesar 5.485 dengan tingkat signifikan sebesar 0,000 Karena signifikannya $0,000<0.05$ maka h0 ditolak, artinya Promosi Penjualan berpengaruh signifikan terhadap Volume Penjualan. 


\section{SIMPULAN DAN SARAN Simpulan}

Berdasarkan dari hasil perhitungan dan pembahasan dari bab sebelumnya, maka penulis dapat menarik kesimpulan dari hasil penelitian ini sebagai berikut :

1. Nilai koefisien determinasi pada tabel 4.4diperoleh nilai R Square sebesar 0,983 atau $98,3 \%$. Artinya pengaruh besarnya variabel independen (Y) adalah $98.3 \%$ sedangkan sisanya sebesar $1,7 \%$ dipengaruhi oleh variabel lain yang tidak diteliti.

2. Berdasarkan hasil uji Regresi yang dapat dilihat pada tabel 4.3 maka diperoleh

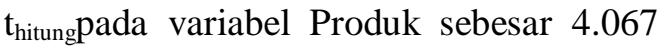
dengan tingkat signifikan 0,000 Karena nilai signifikannya lebih kecil $(<)$ dari pada $(\alpha)$ 0,05 maka h0 ditolak. Dapat disimpulkan bahwa Produk berpengaruh signifikan terhadap Volume Penjualan.

3. Berdasarkan hasil uji Regresi yang dapat dilihat pada tabel 4.3 maka diperoleh $\mathrm{t}_{\text {hitungpada variabel Promosi Penjualan }}$ sebesar 5.485 dengan tingkat signifikan 0,000 Karena nilai signifikannya lebih kecil $(<)$ dari pada $(\alpha)$ 0,05 maka h0 ditolak. Dapat disimpulkan bahwa Promosi Penjualan berpengaruh signifikan terhadap Volume Penjualan.

\section{Saran}

Adapun saran yang akan penulis berikan agar perusahaan dapat memaksimalkan lagi Volume Penjualan yang ada.

1. Untuk Meningkatkan Volume Penjualan maka PT. Delamibrands Kharisma Busana Cabang Palembang perlu untuk mempertahankan atau meningkatkan produk-produk nya dalam segi fashion dan kualitas produk yang berstandar internasional.

2. Memperbaiki dan terus mengembangkan pelayanan kepada konsumen yang ditujukan agar lebih memenuhi harapan dan keinginan konsumen. PT. Delamibrands Kharisma Busana juga harus tetap terfokus pada variabel Promosi Penjualan, mengingat bahwa konsumen menganggap penting peranan tersebut dan sangat disarankan untuk menggunakan lima komponen bauran promosi yang akan memberikan peranan penting sebagai pelengkap kegiatan pemasaran

\section{E. DAFTAR RUJUKAN}

Arikunto, Suharsimi. 2010. Prosedur Penelitian Suatu Pendekatan Praktik. Jakarta: Rineka Cipta.

Azwar, Saifudin. 2012. Metode Penelitian, Yogyakarta: Pustaka Pelajar.

Basu Swasta dan Irawan. 2005. Manajemen Pemasaran Modern.Yogyakarta:Liberty.

Buchari Alma, 2007. Manajemen Pemasaran dan Pemasaran Jasa. Edisi Revisi, Bandung: Alfabeta.

Buchari Alma, 2012. Manajemen Pemasaran dan Pemasaran Jasa. Bandung: Alfabeta.

Fandy Tjiptono. 2008. Strategi Pemasaran (3thed). Yogyakarta : ANDI

Hasan, 2013. Marketing dan Kasus-Kasus Pilihan. Yogyakarta. CAPS (Center For Academic Publishing Service).

Hurryati, Ratih. 2005, Bauran Pemasaran dan Loyalitas Konsumen, Bandung: Alfabeta.

JohnDeighton,Caroline M.Heinderson and Scott A.Neslin, The Effect of Advertising on Brand Switching and Repeat Purchasing, Journal ofMarketing Research, Vol XXXI, February 2001

Kotler, Amstrong. 2001. Prinsip-prinsip pemasaran, Edisi keduabelas, Jilid 1. Jakarta: Erlangga.

Kotler dan Amstrong, Yudhi. 2008. “ Kualitas Produk, Merek dan Desain Pengaruhnya Terhadap Keputusan Pembelian Sepeda Motor Yamaha Mio". Jurnal EMBA. Vol. 1, No.3, Juni.

Kotler, Philip dan Amstrong. 2008. Manajemen Pemasaran. Edisi 13. Jakarta:Erlangga.

Krismiaji. 2002, Sistem Informasi Akuntansi, Jilid 1, Yogyakarta: UPPAMP YKPN

La Midjan. 2001. Sistem Informasi Akuntansi. Bandung : Lingga. Jaya.

Marom, Chairul. 2002. Sistem Akuntansi Perusahaan Dagang. Grasindo: Jakarta

Okki, (2003) "Analisis Pengaruh Tingkat Kesuksesan Produk Baru dalam 
Peningkatan Kinerja Pemasaran.” Jurnal Sains Pemasaran Indonesia, Vol.II No.1 Mei.

Phillip Kotler, 2002. Manajemen Pemasaran. Edisi Millenium, Jilid 2, PT Prenhallindo, Jakarta.

Phillip Kotler dan Amstrong, 2003. Manajemen Pemasaran, Edisi Kesembilan. Jakarta: PT.Indeks Gramedia.

Priyatno, 2010. Teknik Mudah dan Cepat Melakukan Analisis Data Penelitian dengan SPSS dan Tanya Jawab Ujian Pendadaran. Gaya Media, Yogyakarta.

Sarwono, 2006. Metode Penelitian Kuantitatif dan Kualitatif. Yogyakarta: Graha Ilmu.

Simamora, Henry. 2000. Manajemen Pemasaran Internasional,Cetakan Pertama, Salemba Empat, Jakarta

Stanton, W.J. 2001. Marketing, Edisi ke-12, New York, USA:McGraw-Hill Irwin.

Sugiyono. 2008. Metode Penelitian Bisnis. CV Alfabeta, Bandung.

Sugiyono, 2011. Metode Penelitian Kuantitatif, Kualitatif dan R\&D. Bandung: Alfabeta.

Umar, Husein. 2005. Riset Pemasaran dan Perilaku Konsumen. PT. Gramedia Pustaka Utama, Jakarta.

Umi, Narimawati. 2008. Analisis Multifariat untuk Penelitian Ekonomi. Yogyakarta:Graha Ilmu.

Widiyanto.2008. Jumlah volume sampel populasi tak terhingga, Jakarta.

Zeithaml, Valarie A. dan Bitner. 2000. Service Marketing $2^{\text {nd }}$ edition : IntegratingCustomer Focus. New York : Mc Graw Hill Inc. 